Thorax, 1978, 33, 85-88

\title{
Interpretation of lung function tests in the sickle-cell haemoglobinopathies
}

\author{
G. J. MILLER, G. R. SERJEANT, M. J. SAUNDERS, C. RICHARDSON, AND R. J. C. GILSON \\ From the Medical Research Council Pneumoconiosis Unit, Llandough Hospital, Penarth, Glamorgan, \\ South Wales and the Medical Research Council Laboratories, University of the West Indies, \\ Kingston 7, Jamaica
}

Miller, G. J., Serjeant, G. R., Saunders, M. J., Richardson, C., and Gilson, R. J. C. (1978). Thorax, 33, 85-88. Interpretation of lung function tests in the sickle-cell haemoglobinopathies. Prediction equations have been evolved for the assessment of vital capacity, total lung capacity, and the single breath carbon monoxide transfer factor in haemoglobin SS and haemoglobin SC disease. These relationships take account of the growth disorder and anaemia in the sickle-cell states. The results suggest that, in the clinically stable state, any effects of alveolar capillary sickling and haemoconcentration and any altered reactivity of haemoglobins $\mathrm{S}$ and $\mathrm{C}$ with the test gas are of no significance for clinical respiratory physiology. Sex differences in lung function appear independent of haemoglobin type.

The assessment of lung function in the sickle-cell haemoglobinopathies is confounded by several features of this group of disorders. A comparison of results with average normal values for healthy subjects of the same stature is invalidated by a growth disorder characterised by long limbs (Miller and Serjeant, 1971). Alveolar-capillary sickling and haemoconcentration (sludging), and possible differences in reactivity of normal adult haemoglobin and sickle haemoglobin with the test gas, might affect the single breath carbon monoxide transfer factor. The clinical importance of these factors has been assessed by examination of the relationships of lung function with body dimension, haemoglobin concentration, and haemoglobin type, and a system has been evolved for the interpretation of lung function in the sickle-cell states.

\section{Subjects}

Three groups, all of African descent, gave informed consent for study. There were 21 men and 12 women with normal adult haemoglobin ( $\mathrm{Hb}$ AA), 17 men and 16 women with homozygous sickle-cell disease ( $\mathrm{Hb} \mathrm{SS}$ ), and 21 men and 22 women with sickle cell-haemoglobin C disease (Hb SC). The healthy group comprised volunteers drawn from a suburb of Kingston, Jamaica. The patients with haemoglobinopathy attended the sickle-cell clinic of the University Hospital of the West Indies, Jamaica. Diagnostic criteria have been summarised elsewhere (Serjeant, 1974). None had any clinical or radiological evidence of respiratory disease at the time of study, and all were in a clinically stable state. Of the men, five of the healthy group, five with SC disease, and three with SS disease smoked up to 15 cigarettes daily, and one healthy subject smoked 20 cigarettes each day. All women were non-smokers except one with SC disease, who smoked five cigarettes daily.

\section{Methods}

Lung function was measured during the morning with the subject seated upright, using standard techniques (Cotes, 1975) and a semi-automated apparatus (Resparameter; P. K. Morgan Limited). Vital capacity was measured by spirometry, and functional residual capacity and hence total lung capacity were assessed by the closed-circuit helium dilution method. The single-breath carbon monoxide transfer factor was calculated at an alveolar volume obtained by summing the volume of the single breath and the residual volume given by helium dilution (Ogilvie et al., 1957).

Sitting height and standard height (m) were recorded on a stadiometer (Holtain Instruments). A fully erect posture was ensured by the application of gentle traction with the hands over the mastoid 
processes by the investigator. Weight $(\mathbf{k g})$ was measured on a balance scale. Haemoglobin concentration was estimated on peripheral venous blood as cyanmethaemoglobin.

\section{Statistical analysis}

Subjects were grouped by sex and haemoglobin type. Within each group the relationships of the lung function indices with age, standing height, sitting height, weight, and, in the case of the transfer factor, haemoglobin concentration, were explored by multilinear regression analysis. In addition, a 'step-down' regression procedure was used, in which the independent variates were eliminated sequentially in order of least statistical significance, with the analysis repeated at each step until only the significant independent terms remained $(P<0.05)$.

The second stage of the analysis employed the step-down procedure to test whether sex and haemoglobin type made any independent contributions to the prediction of lung function. Dummy variates for sex (male, female), haemoglobin type (SS, SC), and sickle-cell disease (healthy, haemoglobinopathy) were created and used as further independent terms in the analysis, together with the interaction terms of the dummy variates with the continuous variates (for example, sex $\times$ standing height). Thus, for example, in the case of lung volumes the step-down procedure began with four continuous independent variates (age, standing and sitting height, and weight), two dummy variates (sex and haemoglobin type), and eight interaction terms, employing the data for all patients with haemoglobinopathy. The procedure was designed to reject all non-significant interact- tion terms before proceeding to handle the continuous variates. Data could be combined whenever the dummy variate and its interaction terms failed to achieve statistical significance. Finally, whenever the data for SS SC disease could be combined the analysis was repeated, using the dummy variate for sickle-cell disease, in order to determine whether or not the data for healthy subjects and those with haemoglobinopathy could be pooled.

\section{Results}

Table 1 shows that average haemoglobin concentration was lowest in SS disease, that it was similar in females with SC and AA haemoglobin, and that it was lower in SC males than in AA males. The range of haemoglobin concentration in SC disease overlapped those of healthy subjects and SS patients. Standing height was increased, and the ratio of sitting height to standing height was decreased in SS disease compared with the other groups. The greatest group average body weight occurred in the AA groups, the lowest in the SS groups, the SC groups being intermediate.

Table 2 presents the lung volumes and transfer factor by sex and haemoglobin type. Both vital capacity and total lung capacity were reduced in the haemoglobinopathies compared with the healthy group, and transfer factor was significantly reduced in SS disease but not in SC disease.

Vital capacity and total lung capacity increased significantly with increasing standing height in healthy subjects and in men with SC disease, but not in the remaining groups. In contrast, both lung volumes increased significantly with increasing sitting height in all groups, and the slopes of these

Table 1 Means and ranges of age, haemoglobin concentration, and physique, according to sex and haemoglobin type

\begin{tabular}{|c|c|c|c|}
\hline & \multicolumn{3}{|l|}{ Haemoglobin type } \\
\hline & $A A$ & $S C$ & $s S$ \\
\hline $\begin{array}{l}\text { Men } \\
\text { Number } \\
\text { Age (yr) } \\
\text { Haemoglobin (g/dl) } \\
\text { Standing height (m) } \\
\text { Sitting height (m) } \\
\text { Weight (kg) }\end{array}$ & $\begin{array}{l}21 \\
30 \cdot 2(22 \cdot 0-40 \cdot 0) \\
14.9(13 \cdot 0-16 \cdot 7) \\
1 \cdot 73(1 \cdot 65-1 \cdot 96) \\
0.88(0 \cdot 83-0 \cdot 98) \\
65 \cdot 2(52 \cdot 5-83 \cdot 2)\end{array}$ & $\begin{array}{l}21 \\
27 \cdot 1(16 \cdot 0-55 \cdot 0) \\
12 \cdot 7(9 \cdot 3-15 \cdot 0) \\
1 \cdot 73(1 \cdot 61-1 \cdot 87) \\
0 \cdot 89(0 \cdot 84-0 \cdot 97) \\
62.9(53 \cdot 2-74 \cdot 4)\end{array}$ & $\begin{array}{l}17 \\
25 \cdot 1(17 \cdot 0-38 \cdot 0) \\
8 \cdot 0(5 \cdot 8-10 \cdot 3) \\
1 \cdot 75(1 \cdot 65-1 \cdot 85) \\
0 \cdot 86(0 \cdot 81-0 \cdot 91) \\
55 \cdot 8(43 \cdot 2-71 \cdot 8)\end{array}$ \\
\hline $\begin{array}{l}\text { Women } \\
\text { Number } \\
\text { Age (yr) } \\
\text { Haemoglobin (g/dl) } \\
\text { Standing height (m) } \\
\text { Sitting height (m) } \\
\text { Weight (kg) }\end{array}$ & $\begin{array}{l}12 \\
36 \cdot 8(28 \cdot 0-41 \cdot 0) \\
12 \cdot 0(8 \cdot 6-14 \cdot 1) \\
1 \cdot 60(1 \cdot 49-1 \cdot 73) \\
0 \cdot 83(0 \cdot 80-0 \cdot 88) \\
66 \cdot 5(50 \cdot 8-98 \cdot 1)\end{array}$ & $\begin{array}{l}22 \\
26.5(16.0-54.0) \\
11.6(8.7-14.6) \\
1.61(1.47-1.71) \\
0.83(0.75-0.87) \\
56.0(36.4-74.8)\end{array}$ & $\begin{array}{l}16 \\
27.4(19 \cdot 0-40 \cdot 0) \\
8.0(5 \cdot 3-10 \cdot 1) \\
1.64(1.51-1 \cdot 80) \\
0.80(0.74-0.88) \\
53.4(39 \cdot 6-64 \cdot 3)\end{array}$ \\
\hline
\end{tabular}

${ }^{1}$ Ranges in parentheses. 
Table 2 Average values for vital capacity $(V C)$, total lung capacity $(T L C)$, and single breath carbon monoxide transfer factor (TF), according to sex and haemoglobin type

\begin{tabular}{|c|c|c|c|c|c|c|c|}
\hline & \multirow[b]{2}{*}{ No. } & \multicolumn{2}{|l|}{$V C(l)$} & \multicolumn{2}{|c|}{$T L C(l)$} & \multicolumn{2}{|c|}{$\begin{array}{l}T F(\operatorname{mmol} \\
\left.\min ^{-1} \mathrm{kPa}^{-1}\right)\end{array}$} \\
\hline & & Mean & $S D$ & Mean & $S D$ & Mean & $S D$ \\
\hline $\begin{array}{c}\text { Men } \\
\text { AA } \\
\text { SC } \\
\text { SS }\end{array}$ & $\begin{array}{l}21 \\
21 \\
17\end{array}$ & $\begin{array}{l}4 \cdot 27 \\
3 \cdot 70^{2} \\
3 \cdot 35^{3}\end{array}$ & $\begin{array}{l}0.54 \\
0.66 \\
0.64\end{array}$ & $\begin{array}{l}5 \cdot 96 \\
5 \cdot 15^{1} \\
5 \cdot 03^{2}\end{array}$ & $\begin{array}{l}0.78 \\
0.76 \\
0.72\end{array}$ & $\begin{array}{c}11 \cdot 32 \\
10 \cdot 32 \\
7 \cdot 75^{3}\end{array}$ & $\begin{array}{l}1 \cdot 77 \\
2 \cdot 59 \\
1 \cdot 20\end{array}$ \\
\hline $\begin{array}{c}\text { Women } \\
\text { AA } \\
\text { SC } \\
\text { SS }\end{array}$ & $\begin{array}{l}12 \\
22 \\
16\end{array}$ & $\begin{array}{l}3.08 \\
2.55^{2} \\
2.45^{2}\end{array}$ & $\begin{array}{l}0.33 \\
0.35 \\
0.42\end{array}$ & $\begin{array}{l}4.41 \\
3.63^{2} \\
3.99\end{array}$ & $\begin{array}{l}0.57 \\
0.52 \\
0.57\end{array}$ & $\begin{array}{l}7 \cdot 57 \\
6 \cdot 78 \\
5 \cdot 99^{2}\end{array}$ & $\begin{array}{l}0.86 \\
1.51 \\
0.91\end{array}$ \\
\hline
\end{tabular}

Value significantly different from AA group: ${ }^{1} \mathrm{P}<0.05$; ${ }^{2} \mathrm{P}<0.01$; ${ }^{3} \mathrm{p}<0.001$.

relationships were common to both sexes and to all three haemoglobin types. The constant term of the regression relationship did not differ significantly between SS and SC disease in either sex, which meant that the data for these groups could be combined, but lung volumes at standard sitting height were significantly smaller in the sickle-cell states than in healthy subjects, and were smaller in women than in men. These differences are indicated in Table 3 by the regression coefficients for sickle-cell disease and sex. Age did not improve the prediction of lung volumes in this study. The residual standard deviations about the two regressions were of similar order to those for other adult series (Cotes, 1975).

Transfer factor increased significantly with increasing standing height and sitting height in healthy subjects but no similar relationships were apparent in any of the groups possessing haemoglobin S, even after allowance for age and haemoglobin concentration. Positive and statistically significant correlations were found between transfer factor and total lung capacity in men with AA and SC haemoglobin, and in women with SS di- sease; and between transfer factor and haemoglobin concentration in all female groups and in men with SS disease. Transfer factor declined significantly with age in healthy women and in men with SC disease. The step-down regression procedure produced the multilinear regression relationship presented as Table 4. The best fitted regression was obtained when transfer factor and haemoglobin concentration were expressed in reciprocal form. Table 4 shows that the partial regression coefficients of transfer factor on haemoglobin concentration, total lung capacity, and age were common to all groups, and that transfer factor at standard lung volume, haemoglobin concentration, and age did not differ significantly with haemoglobin type. The positive partial regression coefficient on sex indicates a smaller transfer factor in women than in men irrespective of haemoglobin type.

Table 4 Regression relationship for prediction of reciprocal of single breath carbon monoxide transfer factor ( $\mathrm{mmol} \mathrm{min}^{-1} \mathrm{kPa}^{-1}$ ), according to total lung capacity, haemoglobin concentration, age, and sex

\begin{tabular}{|c|c|c|c|}
\hline & $\begin{array}{l}\text { Regression } \\
\text { coefficient }\end{array}$ & $\pm S E$ & $\mathbf{P}$ \\
\hline $\begin{array}{l}\text { Independent variates } \\
\text { Reciprocal of haemoglobin } \\
\text { concentration (mg/dl) } \\
\text { Total lung capacity (l) } \\
\text { Age (yr) } \\
\text { Sex }^{1}\end{array}$ & $\begin{array}{l}+0.531 \\
-0.012 \\
+0.0006 \\
+0.023\end{array}$ & $\begin{array}{l}0.076 \\
0.003 \\
0.0002 \\
0.006\end{array}$ & $\begin{array}{l}<0.001 \\
<0.001 \\
<0.05 \\
<0.001\end{array}$ \\
\hline $\begin{array}{l}\text { Constant term } \\
\text { Residual standard deviation }\end{array}$ & $\begin{array}{r}+0.110 \\
0.021\end{array}$ & & \\
\hline
\end{tabular}

${ }^{1}$ Male $=0 ;$ female $=1$.

\section{Discussion}

The prediction equations presented have been found to be of use in the assessment of pulmonary disease in the sickle-cell disorders. Lung volumes

Table 3 Regression relationships for prediction of average normal vital capacity and total lung capacity, according to sitting height, sickle-cell state, and sex

\begin{tabular}{|c|c|c|c|c|c|c|}
\hline & \multicolumn{3}{|c|}{ Vital capacity (1) } & \multicolumn{3}{|c|}{ Total lung capacity (1) } \\
\hline & $\begin{array}{l}\text { Regression } \\
\text { coefficient }\end{array}$ & $\pm S E$ & $\mathbf{P}$ & $\begin{array}{l}\text { Regression } \\
\text { coefficient }\end{array}$ & $\pm S E$ & $\mathbf{P}$ \\
\hline $\begin{array}{l}\text { Independent variates } \\
\text { Sitting height (m) } \\
\text { Sickle-cell disease } \\
\text { Sex }^{2}\end{array}$ & $\begin{array}{l}+8 \cdot 76 \\
-0.74 \\
-0.56\end{array}$ & $\begin{array}{l}1 \cdot 60 \\
0 \cdot 15 \\
0 \cdot 14\end{array}$ & $\begin{array}{l}<0.001 \\
<0.001 \\
<0.001\end{array}$ & $\begin{array}{l}+8.97 \\
-0.89 \\
-0.89\end{array}$ & $\begin{array}{l}2 \cdot 23 \\
0 \cdot 21 \\
0 \cdot 20\end{array}$ & $\begin{array}{l}<0.001 \\
<0.001 \\
<0.001\end{array}$ \\
\hline $\begin{array}{l}\text { Constant term } \\
\text { Residual standard deviation }\end{array}$ & $\begin{array}{r}-3 \cdot 37 \\
0 \cdot 43\end{array}$ & & & $\begin{array}{r}-1 \cdot 85 \\
0.61\end{array}$ & & \\
\hline
\end{tabular}

${ }^{1}$ Haemoglobin SS or $\mathrm{SC}=1$; haemoglobin $\mathrm{AA}=0$.

${ }^{2} \mathrm{Male}=0 ;$ female $=1$. 
are assessed in terms of sitting height, and then the magnitude of the transfer factor is assessed in terms of actual lung volume, haemoglobin concentration, age, and sex. The relationships also have a place in research. Thus, in SC disease, the frequency of gross retinal vascular disease (retinitis proliferans) increases sharply at haemoglobin concentrations above $12 \mathrm{~g} / \mathrm{dl}$, an observation which suggested that vessel disease was related to high viscosity with retardation of flow in small vessels (Condon and Serjeant, 1972). There was a need to ascertain whether this effect was confined to the retina or whether a similar phenomenon occurred in other capillaries, including those of the pulmonary alveoli. A plot of the difference between measured and predicted values for transfer factor against haemoglobin concentration revealed no systematic trend to a decline in gas transfer ability at high haemoglobin concentration in SC disease. On this account any viscosity effect in SC disease did not appear to be of clinical importance. This conclusion was supported by measurement of the physiological dead-space. At rest, patients with a haemoglobin concentration exceeding $14 \mathrm{~g} / \mathrm{dl}$ had an average physiological dead-space of 0.181 (range $0 \cdot 13-0.321$ ) and a dead-space/tidal volume ratio of 0.36 (range $0.28-0.41$ ), the latter decreasing during exercise. These results indicate a lack of abnormal dead space ventilation (Jones and Goodwin, 1965). Peripheral vascular changes in SC disease are probably of clinical importance only in the retina.

The regression relationship in Table 4, common to all three haemoglobin types, suggests that affects such as 'sludging' in the alveolar capillary bed and altered reactivity of the test gas with haemoglobin $S$ are of little importance for clinical respiratory physiology, at least when patients are in a steady state. Similar relative affinity constants for carbon monoxide with $\mathrm{Hb} \mathrm{A}$ and $\mathrm{Hb} \mathrm{S}$ over a range of temperatures have been described by Rodkey et al. (1974), but the reactivity of this gas with $\mathrm{Hb} \mathrm{S}$ is still unknown.

The suitability of these prediction relationships for healthy subjects of African descent and for those with SS or SC disease can be assessed by comparison of measured and predicted mean values for each group, as in Table 5. Agreement is good for all male groups and for females with SC disease. In healthy females and women with SS disease, the discrepancies are somewhat larger $\overline{\bar{c}}$ but the probability was that these differences were $\mathbb{Q}$ due to chance alone $(\mathrm{P}>0.05)$.

Table 5 Predicted average lung function expressed as a fraction of measured means for vital capacity. total lung capacity, and the reciprocal of the transfer factor

\begin{tabular}{llll}
\hline & Vital capacity & $\begin{array}{l}\text { Total lung } \\
\text { capacity }\end{array}$ & $\begin{array}{l}\text { Reciprocal of } \\
\text { transfer factor }\end{array}$ \\
\hline $\begin{array}{l}\text { Haemoglobin AA } \\
\text { Males }\end{array}$ & 1.016 & 1.014 & 1.045 \\
$\begin{array}{l}\text { Females } \\
\text { Haemoglobin SC }\end{array}$ & 1.085 & 1.067 & 1.061 \\
$\quad$ Males & 0.997 & 1.018 & 1.046 \\
$\begin{array}{l}\text { Females } \\
\text { Haemoglobin SS }\end{array}$ & 1.020 & 1.051 & 0.987 \\
$\quad$ Males & 1.006 & 0.971 & 1.012 \\
Females & 0.941 & 0.882 & 0.988 \\
\hline
\end{tabular}

\section{References}

Condon, P. I., and Serjeant, G. R. (1972). Ocular findings in hemoglobin SC disease in Jamaica. American Journal of Ophthalmology, 74, 921-931. \&

Cotes, J. E. (1975). Lung Function. Assessment and $\mathbb{Q}$ Application in Medicine. Blackwell, Oxford.

Jones, N. L., and Goodwin, J. F. (1965). Respiratory function in pulmonary thrombo-embolic disorders. British Medical Journal, 1, 1089-1093.

Miller, G. J., and Serjeant, G. R. (1971). An assessment of lung volumes and gas transfer in sickle-cell anaemia. Thorax, 26, 309-315.

Ogilvie, C. M., Forster, R. E., Blakemore, W. S., and Morton, J. W. (1957). A standardised breath-holding technique for the clinical measurement of the diffusing capacity of the lung for carbon monoxide. $\stackrel{\circ}{\circ}$ Journal of Clinical Investigation, 36, 1-17.

Rodkey, F. L., O'Neal, J. D., Collison, H. A., and Uddin, D. E. (1974). Relative affinity of hemoglobin? $\mathrm{S}$ and $\mathrm{A}$ for carbon monoxide and oxygen. Clinical Chemistry, 20, 83-84.

Serjeant, G. R. (1974). Clinical Features of Sickle Cell Nু Disease. North Holland Publishing Company, Amsterdam.

Requests for reprints to: Dr. G. J. Miller, 16-19ס Jamaica Boulevard, PO Box 164, Federation Park, Port-of-Spain, Trinidad, West Indies. 